\title{
PENEGAKAN HAK ASASI MANUSIA TERKAIT NEW YORK AGREEMENT 1962 DALAM HAL PENENTUAN PENDAPAT RAKYAT PAPUA
}

\author{
Mukti Stoffel \\ Fakultas Hukum Universitas Yapis Papua \\ Email : muktistoffel@gmail.com
}

\begin{abstract}
Abstrak
Implementasi Hasil Penentuan Pendapat Rakyat (PEPERA) berdasarkan New York Agreement 1962 dalam kaitannya dengan Penegakan Hak Asasi Manusia di Tanah Papua menunjukkan bahwa Pemerintah Indonesia pada tahun 1969 berusaha menggerakkan pembangunan dengan meminggirkan pengalaman dan nilai-nilai social budaya rakyat Papua. Ketidakseimbangan kehidupan sosial masyarakat yang diperkuat dengan adanya beberapa kelompok masyarakat yang tidak mendukung hasil Pepera menyebabkan muncullah kelompok-kelompok masyarakat Papua yang pro dan kontra terhadap pembangunan. Apabila menginginkan Papua ini menjadi wilayah yang aman pemerintah harus memikirkan bagaimana seluruh masyarakat Papua bisa hidup sejahtera, memiliki rasa aman dan meminimalisir kesenjangan antar daerah/wilayah di Negara Kesatuan Republik Indonesia. Kesejahteraan hidup didambakan oleh semua pihak. Bila hidup sejahtera dan aman maka pergolakan akan berkurang.
\end{abstract}

Kata kunci: New York Agreement 1962, Pepera 1969, HAM di Tanah Papua

\begin{abstract}
The results of this study indicate that the Implementation of the Results of the Decision of the People's Opinion (PEPERA) based on the 1962 New York Agreement in relation to the Enforcement of Human Rights in Papua shows that the Indonesian Government in 1969 sought to mobilize development by marginalizing the experiences and social cultural values of the Papuan people. The imbalance of the social life of the community which is reinforced by the existence of several community groups that do not support the results of the Act of Free Choice has led to the emergence of Papuan groups that are pro and contra to development. If you want Papua to be a safe area the government must think about how all Papuans can live in prosperity, have a sense of security and minimize gaps between regions / regions in the Unitary State of the Republic of Indonesia. Life welfare is coveted by all parties. If life is prosperous and safe, the upheaval will decrease.
\end{abstract}

Keywords: New York Agreement 1962, February 1969, Human Rights in the Land of Papua

\section{PENDAHULUAN}

Tahun 2001 merupakan awal pelaksanaan otonomi khusus di Papua. Penyelenggaraan otonomi khusus di Papua beranjak dari kondisi masyarakat 


\section{$\mathcal{H}$ urnal Negara dan Keadilan \\ p-ISSN 2302-7010 e-ISSN 2721-9801}

Papua yang 'merasa' dilupakan, dipinggirkan sementara hasil bumi di Wilayah ini sangat luas dan memberikan kontribusi besar bagi Negara Kesatuan Republik Indonesia. Banyak rakyat Papua yang kecewa dengan Pemerintah Indonesia sehingga tidak sedikit terjadi perselisihan dan pemberontakan di Wilayah Papua. Banyak faktor yang mempengaruhi, diantaranya mereka merasa bahwa bergabungnya Papua ke dalam Wilayah Negara Kesatuan Republik Indonesia merupakan sebuah 'keterpaksaan'.

Bila menoleh ke belakang bahwa proses bergabungnya Papua ke dalam NKRI di latar belakangi oleh 'New Agreement 1962' sebagai pencetus adanya Penentuan Pendapat Rakyat (Pepera) 1969. Hak atas penentuan nasib sendiri merupakan hak asasi manusia yang fundamental dan tidak terpisahkan dari diri seorang manusia. Hak ini dicantumkan dalam dua instrumen utama yaitu instrumen hak asasi manusia (Perjanjian Internasional mengenai Hak-hak Sipil dan Politik dan Perjanjian Internasional mengenai hak-hak Ekonomi, Sosial dan Budaya). Mengingat pentingnya hak ini bagi tatanan internasional dan perlindungan hak-hak individu. Mahkamah Pengadilan Internasional mengakui hak atas penentuan nasib sendiri sebagai hak asasi manusia yang paling penting, termasuk dalam hal ini adalah pelaksanaan Pepera (Penentuan Pendapat Rakyat) di Tanah Papua yang berakhir Tahun 1969. Namun, setelah selesainya pelaksanaan hak menentukan nasib sendiri bagi masyarakat Papua, justru hak-hak mereka sebagai masyarakat bangsa Negara Kesatuan Republik Indonesia dilupakan bahkan dilanggar oleh Negara.

Komnas Perempuan Republik Indonesia dalam buku Stop Sudah! Kesaksian Perempuan Papua Korban Kekerasan dan Pelenggaran HAM 19632009, menyatakan bahwa, telah terjadi beberapa pelanggaran Hak Asasi Manusia di Tanah Papua. Sebagai contoh apa yang dikemukakan oleh Komnas Perempuan RI bahwa kekerasan oleh negara yang termasuk pelanggaran HAM di Tanah Papua dikategorikan dalam dua periode masa kelam pelanggaran HAM yaitu periode antara Tahun 1963-1998 dan pada periode antara Tahun 1999-2009. Periode antara Tahun 1963-1988, mencakup masa transisi wilayah Papua dari penyerahan United Nations Temporary Executive Authority (UNTEA) menjadi bagian dari Indonesia sampai pada periode reformasi. Pada masa rezim Orde Baru ini, seperti di wilayah-wilayah konflik lain di Indonesia, negara menggunakan pendekatan keamanan terhadap kelompok-kelompok sipil yang melakukan perlawanan terhadap ketidakadilan termasuk serta mengedepankan kepentingan pengusaha dan pemerintah pusat tanpa berupaya memahami akar masalah dari keresahan masyarakat Papua. Demikian pula, perempuan terseret dalam arus konflik yang deras di berbagai wilayah dan mengalami berbagai bentuk kekerasan. ${ }^{1}$

Sedangkan periode antara Tahun 1999 sampai dengan Tahun 2009, atau dikenal dengan orde reformasi ditemukan bahwa kekerasan negara yang termasuk dalam perbuatan pelanggaran HAM rupanya tidak berhenti. Tim pendokumentasian memulai proses pengumpulan kesaksian-kesaksian perempuan korban kekerasan negara dengan sebuah pertanyaan, "Apakah situasi kekerasan

${ }^{1}$ Komnas Perempuan Republik Indonesia, Stop Sudah! Kesaksian Perempuan Papua Korban Kekerasan dan Pelanggaran HAM 1963-2009. Hasil Pendokumentasian Bersama Kelompok Kerja Pendokumentasian Kekerasan \& Pelanggaran HAM Perempuan Papua, 2009-2010. hlm. 21. 


\section{Hurnal Negara dan $\mathcal{X}$ eadilan \\ p-ISSN 2302-7010 e-ISSN 2721-9801}

ini membaik dengan era reformasi yang menghantarkan otonomi khusus?" Hasilnya, harapan untuk menemukan perbaikan berubah menjadi kekecewaan dengan kenyataan bahwa pendekatan keamanan masih menjadi cara utama yang dipakai pemerintah untuk menghadapi ketidakpuasan masyarakat. Bahkan dalam periode ini beberapa peristiwa kekerasan mengemuka, seperti kasus-kasus, yang menurut kesimpulan Komnas HAM, mengindikasikan kejahatan terhadap kemanusiaan, seperti kasus Abepura, Wasior, dan lain-lain. Perilaku oknum aparat keamanan yang sewenang-wenang dan diskriminasi terhadap orang-orang yang dianggap separatis berimbas pula pada berbagai bentuk kekerasan terhadap perempuan, termasuk kekerasan seksual. ${ }^{2}$

\section{METODE PENELITIAN}

Penelitian hukum normatif adalah penelitian yang dilakukan dengan meneliti bahan hukum pustaka atau data sekunder, yang mencakup bahan hukum primer, sekunder dan tertier. Sedangkan penelitian hukum empiris atau sosilogis adalah penelitian hukum yang dilakukan dengan meneliti data sekunder, yang kemudian dilanjutkan dengan penelitian terhadap data primer di lapangan atau terhadap masyarakat (penelitian terhadap identifikasi hukum dan penelitian terhadap efektifitas hukum). Jalan penelitian yang dilakukan dalam penelitian ini dibagi menjadi 3 (tiga) tahapan penelitian, yaitu tahapan persiapan, tahapan pelaksanaan penelitian, tahapan penyelesaian.

\section{PEMBAHASAN}

Konflik dan kekerasan negara yang terjadi di Papua disebabkan oleh perbedaan persepsi sejarah integrasi Papua antara pemerintah Republik Indonesia (RI) dan rakyat Papua. Pemerintah RI menganggap bahwa integrasi Papua ke dalam RI telah resmi berdasarkan hasil Penentuan Pendapat Rakyat, sedangkan rakyat Papua beranggapan bahwa proses Pepera berjalan di bawah intimidasi dan kecurangan, serta tidak mempraktekan kebiasaan internasional di mana setiap orang dewasa berhak menentukan pilihan politiknya secara langsung. Indonesia mengusulkan tata cara pemungutan suara dengan sistem musyawarah, hal mana sangat bertentangan dengan praktek Internasional. Sebanyak 1025 orang telah dipilih tanpa mekanisme yang jelas, dan dianggap oleh RI representatif mewakili sedikitnya 800.000 orang Papua pada saat itu. Selain dilakukan di bawah ancaman dan intimidasi. Terjadi letupan-letupan perlawanan seperti di Wahgete dan Enarotali, Paniai. ${ }^{3}$

Kekerasan Negara adalah semua bentuk kekerasan terhadap masyarakat di tanah Papua, bahkan tidak terkecuali juga bagi para perempuan yang dimana secara langsung mengalami kekerasan fisik, seksual, psikologi yang dilakukan atau didukung oleh aparat kemanan (tentara, polisi) dan aparat pemerintah. Termasuk dalam golongan kekerasan ini adalah kekerasan yang tidak dilakukan secara langsung oleh aparat Negara, tetapi dibiarkan atau pun didukung oleh aparat Negara misalnya yang dilakukan oleh kelompok seperti milisi atau penjaga keamanan di perusahaan. ${ }^{4}$

Kegalauan yang melanda Indonesia pada saat Presiden Soeharto mengukuhkan kekuasaannya pada awal Orde Baru juga berdampak di wilayah

\footnotetext{
2 Ibid., hlm. 31

${ }^{3}$ Ibid., hlm. 6.

${ }^{4}$ Ibid., hlm. 20.
} 


\section{$\mathcal{H}$ urnal Negara dan Keadilan \\ p-ISSN 2302-7010 e-ISSN 2721-9801}

Papua. Secara konkret operasi militer bernama Operasi Sadar (1965-1967) dikerahkan untuk menumpas perbedaan pendapat di Papua, bahkan dalam waktu beberapa tahun saja, pemerintah Indonesia sudah dapat menandatangani sebuah kontrak karya dengan PT. Freeport McMoran, yang menyerahkan jutaan hektare tanah untuk eksploitasi tambang pada bulan April 1967. Ironisnya, kontrak karya ini ditandatangani dua tahun sebelum penentuan status dan hak orang Papua oleh orang Papua melalui "Pepera" (Penentuan Pendapat Rakyat) pada Tahun 1969, yang juga disaksikan dan didukung oleh perwakilan PBB.$^{5}$

Masa reformasi membuka peluang baru untuk mengungkapkan kekecewaan masyarakat papua atas kesewenangan pemerintah orde baru. Pada bulan juli 1998, 500 orang mahasiswa Universitas Cendrawasih (UNCEN) di Abepura, kota jayapura provinsi papua, berdemonstrasi di depan gedung administrasi UNCEN untuk menuntut demiliterisasi papua barat dan diselenggarakannya referendum baru serta peninjauan ulang kesepakatan New York Agreement 1962. Momentum reformasi juga membuka pengakuan resmi terhadap adanya persoalan pelanggaran HAM di tanah Papua, pengakuan tersebut tertera dalam Bab IV, huruf G, butir 2, poin (b) TAP MPR Nomor IV/MPR/1999 tentang Garis-Garis Besar Haluan Negara (GBHN) Tahun 1999-2004 oleh Sidang Umum MPR tanggal 19 Oktober 1999, yang menyatakan komitmen Negara untuk "menyelesaikan kasus pelanggaran Hak Asasi Manusia (HAM) di Irian Jaya melalui proses pengadilan yang jujur dan bermartabat...". Namun, komitmen tersebut hanyalah sebuah komintmen negara yang tidak dilaksanakan secara konsisten oleh negara, pelanggaran HAM di tanah Papua tidak kujung selesai, suasana tegang kembali melanda tanah Papua pada tanggal 7 Desember 2000, sekelompok orang melakukan penyerangan terhadap Polsek Abepura, sehinggah memicu kembali dilakukannya operasi balasan oleh Brimob yang di mana menahan dan menyiksa ratusan orang, serta membunuh tiga orang yang telah ditangkap.

Belajar dari negara-negara Eropa Timur dan Lepasnya Timor Timur melalui referendum, bukan merupakan suatu hal yang mustahil kejadian serupa akan terjadi lagi di Tanah Papua jika kekerasan dan perbuatan pelanggaran HAM masih tetap berkelanjutan. Pada awalnya Timor Timur adalah daerah yang tidak bertuan yang ditinggalkan oleh Portugis. Namun dengan hadirnya militer Indonesia Kekerasan di Timor Timur menguat, terjadi pelanggaran HAM di mana-mana. Militer Indonesia memasuki wilayah tersebut sejak Tahun 1975 dengan pembentukan dan penggalangan sipil bersenjata yang di kemudian disebut hari Wanra (perlawanan rakyat). Sebagian dari tenaga-tenaga tersebut diorganisir ke dalam TNI melalui program militerisasi atau milsas dan digaji sebagai tentara reguler. Milsas oleh para pejabat tinggi militer di Jakarta disebut sebagai anggota TNI putra daerah dan mereka hanya bertugas di Timtim dalam membantu operasi TNI di Timor Timur, dan elit dari kelompok Pro-integrasi dijadikan pejabat birokrasi. Contohnya adalah Joao Tavares - Bupati Bobonaro sekaligus pemimpin satuan Halilintar. ${ }^{6}$

\footnotetext{
${ }^{5}$ Ibid., hlm. 8

6 Komnas Hak Asasi Manusia. Ringkasan Eksekutif Laporan Penyelidikan Pelanggaran Hak Asasi Manusia di Timor Timur. 31 Januari 2000. Jakarta. hlm.4.
} 


\section{Hurnal Negara dan $\mathcal{X}$ eadilan \\ p-ISSN 2302-7010 e-ISSN 2721-9801}

Pola pelanggaran Hak Asasi Manusia (HAM) yang terjadi di Timor Timur menurut KPP HAM berdasarkan fakta, dokumen, keterangan dan kesaksian dari berbagai pihak menemukan tindakan yang dapat digolongkan sebagai pelanggaran berat Hak Asasi Manusia atau 'Gross Violation Of Human Rights' yang menjadi tanggung jawab negara (State Responsibilities), namun dapat dipastikan, seluruh pelanggaran berat Hak Asasi Manusia itu dapat digolongkan ke dalam Universal Jurisdiction, yaitu mencakup pembunuhan, pemusnahan, perbudakan, pengusiran dan pemindahan paksa serta lain-lain tindakan tidak manusiawi terhadap penduduk sipil, ini adalah pelanggaran berat atas hak hidup (the right to life), hak atas integritas jasmani (the right to personal integrity), hak akan kebebasan (the right to liberty) hak akan kebebasan bergerak dan bermukim (the right of movement and to residance), serta hak milik (the right to property). ${ }^{7}$

Permasalahan sebagaimana diuraikan di atas mengundang reaksi internasional yang akhirnya menekan Pemerintah Indonesia untuk bertanggung jawab atas berbagai perbuatan pelanggaran Hak Asasi Manusia di Timor Timur. Kemudian, Pada bulan Juni 1998, Presiden Habibie menawarkan otonomi terbatas di dalam Indonesia kepada Timor Timur. Tujuh bulan kemudian, pada bulan Januari 1999, Presiden Habibie menawarkan pelaksanaan hak penentuan nasib sendiri di bawah supervisi PBB. Pemilihan suara dilakukan pada tanggal 30 Agustus 1999, dan menghasilkan pilihan kemerdekaan secara penuh. Pada tanggal 20 Oktober 1999, MPR Republik Indonesia mengakui hasil tersebut, dan mencabut dekrit Tahun 1976 yang memasukkan Timor Timur ke dalam wilayah Indonesia, dan Pada tanggal 1 November 1999, pasukan-pasukan terakhir TNI meninggalkan wilayah Timor Leste.

Apa yang terjadi di Timor Leste sebelum pelaksanaan jajak pendapat kini juga terjadi di Tanah Papua. Kekerasan dan pelanggaran HAM yang terjadi di Tanah Papua menguat setelah pelaksanaan Penentuan Pendapat Rakyat (Pepera) atau referendum, Keputusan Rakyat Papua untuk mengintergrasikan diri tanah airnya ke dalam Negara Kesatuan Republik Indonesia hingga kini justru dijawab dengan berbagai tindakan kekerasan yang di mana berujung pada perbuatan pelanggaran Hak Asasi Manusia.

New York Agreement 1962 merupakan perjanjian internasional yang diprakarsai oleh Organisasi Perserikatan Bangsa-Bangsa dalam menengahi antara Pemerintah Indonesia dan masyarakat Irian Jaya, yang saat ini dikenal dengan Papua. Perjanjian New York Agreement 1962 mengamanatkan bahwa PBB harus melakukan transfer lengkap secara administratif kepada Pemerintah Indonesia, Kemudian Pemerintah Indonesia akan melakukan act of free choice (penentuan pendapat rakyat) secara penuh terhadap Irian Barat. Pelaksanaan Penentuan pendapat rakyat oleh Pemerintah Indonesia tentu saja berdasarkan saran dan bantuan Sekretaris Jenderal PBB. Kesulitan dalam memilih metode dan prosedur yang tepat untuk pelaksanaan Pepera adalah diakui oleh pemerintah Indonesia. Hal ini diakibatkan karena berkaitan dengan kondisi manusia, situasi geografis dan sosial, serta masalah kendala teknis lain yang dipertimbangkan. Penentuan Pendapat Rakyat akhirnya dilaksanakan tahun 1969. Sementara dalam perkembangannya hasil Pepera menimbulkan pro dan kontra, dimana wilayah Papua sejak bergabung dengan NKRI menimbulkan banyak permasalahan terutama terkait dengan penegakan Hak Asasi Manusia.

${ }^{7}$ Ibid., hlm. 5-7. 


\section{Zurnal Negara dan $\mathcal{X}$ eadilan \\ p-ISSN 2302-7010 e-ISSN 2721-9801}

Pemerintah Indonesia pada tahun 1969 berusaha menggerakkan pembangunan dengan meminggirkan pengalaman dan nilai-nilai social budaya rakyat Papua. Bukti nyata pergerakan pembangunan di Papua adalah dengan adanya program transmigrasi, namun bagi masyarakat Papua program ini lebih menyentuh kepada kepentingan pemerintah Indonesia yang lebih mengarah pemindahan penduduk padat ke daerah yang masih jarang penduduknya dengan system sentralistik dan top down yang menyebabkan tanah papua menjadi obyek pembangunan dengan kondisi wilayah paling timur dan jauh secara kultural.

Ketidakseimbangan kehidupan sosial masyarakat yang diperkuat dengan adanya beberapa kelompok masyarakat yang tidak mendukung hasil Pepera menyebabkan muncullah kelompok-kelompok masyarakat Papua yang pro dan kontra terhadap pembangunan. Bagi mereka yang bertentangan dengan pemerintah Indonesia membentuk gerakan-gerakan melawan pemerintah seperti gerakan Organisasi Papua Merdeka yang lebih dikenal dengan istilah "OPM". Peran dominasi militer yang tinggi di Papua dan eksploitasi sumber daya alam tanpa keseimbangan umpan balik pemerintah pusat semakin memperburuk keadaan yaitu ketidakpercayaan masyarakat papua terhadap pemerintah pusat. Sehingga pada tahun 1998 masyarakat Papua menuntut demiliterisasi Papua Barat dan diselenggarakannya referendum baru serta peninjauan ulang kesepakatan $\mathrm{New}$ York Agreement.

Nilai dasar ini belum menyentuh harapan masyarakat dikarenakan masih terjadinya banyak pelanggaran HAM di Papua. Apabila menginginkan Papua ini menjadi wilayah yang aman pemerintah harus memikirkan bagaimana seluruh masyarakat Papua bisa hidup sejahtera, memiliki rasa aman dan meminimalisir kesenjangan antar daerah/wilayah di Negara Kesatuan Republik Indonesia. Kesejahteraan hidup didambakan oleh semua pihak. Bila hidup sejahtera dan aman maka pergolakan akan berkurang. Peran dari militer masih diperlukan namun diminimalkan fungsinya hanya sebagai peran mengayomi masyarakat bukan menjadi musuh atau penegak hukum. Militer berperan sebagai pelindung masyarakat. Seperti yang berlaku di Negara Malaysia. Polisi hanya sebagai pelindung masyarakat sipil. Dengan bantuan peraturan hukum melalui UndangUndang yang tegas tanpa memihak maka Papua damai dapat terwujud. Meminimalisir kesenjangan Wilayah Papua dengan Wilayah lain di bagian barat Indonesia dengan menyediakan sarana dan prasarana transportasi dengan penentuan harga yang berbeda dengan wilayah lain di Indonesia. Penyeragaman harga transportasi yang tanpa melihat jarak perlu dipikirkan pemerintah jika ingin Papua menjadi tanah damai.

Melalui Presiden Gus Dur di tahun 1999 guna menjawab aspirasi masyarakat Papua ditetapkanlah Papua sebagai Daerah dengan status Otonomi Khusus. Adapun nilai-nilai dasar yang dimaksud dalam nilai-nilai Otonomi Khusus Papua adalah:

\section{Perlindungan terhadap Hak-hak Dasar Penduduk Asli Papua}

Perlindungan ini dimaksudkan untuk memungkinkan masyarakat Papua dapat mengembangkan kemampuan diri yang dikaruniakan Tuhan kepadanya secara baik dan bermartabat, sehingga dalam waktu secepat- 


\section{Hurnal Negara dan $\mathcal{X}$ eadilan \\ p-ISSN 2302-7010 e-ISSN 2721-9801}

cepatnya rakyat Papua dapat menjadi warga negara Indonesia dan anggota masyarakat dunia yang modern dan sejajar dengan bangsa-bangsa maju manapun dengan tidak meninggalkan identitas jati dirinya. Perlindungan akan hak-hak dasar tidak dapat dipisahkan dari kewajiban-kewajiban yang melekat pada orang-orang asli Papua, bahkan seluruh penduduk Papua, sebagai makhluk ciptaan Tuhan, warga masyarakat dan warga negara.

Demokrasi dan Kedewasaan Berdemokrasi

Bermusyawarah untuk mencapai kata mufakat merupakan tradisi kehidupan masyarakat Papua sejak dulu. Sistem kepemimpinan di hampir semua suku di Papua adalah kepemimpinan kolektif yang menunjukan tentang perlunya dicapai konsensus-konsensus yang memberikan manfaat bagi semua pihak. Selain itu, kesempatan untuk mencapai posisi pemimpin terbuka bagi setiap anggota masyarakat sepanjang ia memenuhi syaratsyarat tertentu terutama kemampuan untuk memberikan pengayoman kepada anggota mayarakat yang dipimpinnya.

Kebudayaan demokrasi orang Papua perlu terus diberdayakan dan dilestarikan. Hal ini merupakan modal dasar dan kekuatan yang ampuh untuk memastikan bahwa setiap keputusan penting yang menyangkut orang Papua tidak bertentangan dengan nilai-nilai yang dianut dan tidak mengurangi, bahkan mampu mengembangkan, harkat hidup orang Papua.

Penghargaan tehadap Etika dan Moral

Etika dan moral merupakan tuntutan hidup orang Papua sejak dahulu. Etika dan moral ini kemudian diperkaya oleh ajaran-ajaran agama Kristen Protestan, Katolik, Islam dan agam-agama lain yang dipeluk oleh orang Papua sejak kurang lebih 200 tahun lalu. Penghargaan etika dan moral inilah yang memungkinkan Tanah Papua hingga saat ini masih jauh lebih aman dibandingkan beberapa daerah tertentu di Indonesia, walaupun ada pihak-pihak yang terus-menerus menyebarluaskan kesan bahwa Papua adalah daerah yang rawan keamanan. Hubungan sosial yang erat dan saling menghormati antar sesama warga Tanah Papua yang terus dipertahankan bahkan dikembangkan hingga saat ini adalah akibat adanya penghargaan terhadap etika dan moral yang telah ada sejak dahulu.

\section{DAFTAR PUSTAKA}

Komnas Perempuan Republik Indonesia, Stop Sudah! Kesaksian Perempuan Papua Korban Kekerasan dan Pelanggaran HAM 1963-2009. Hasil Pendokumentasian Bersama Kelompok Kerja Pendokumentasian Kekerasan \& Pelanggaran HAM Perempuan Papua, 2009-2010.

Komnas Hak Asasi Manusia. Ringkasan Eksekutif Laporan Penyelidikan Pelanggaran Hak Asasi Manusia di Timor Timur. 31 Januari 2000. Jakarta. 